\title{
Strategies and economics of farming systems with coffee in the Atlantic Rainforest Biome
}

\author{
Helton Nonato de Souza • Jan de Graaff • \\ Mirjam M. Pulleman
}

Received: 14 April 2011/ Accepted: 31 October 2011/Published online: 19 November 2011

(C) The Author(s) 2011. This article is published with open access at Springerlink.com

\begin{abstract}
In the Zona da Mata of Minas Gerais State, Brazil, family farmers are adjusting to agroecological principles to reconcile sustainable agriculture, livelihood improvements and biodiversity conservation. Starting in 1993, experimentation with coffee agroforestry was gradually initiated on an increasing number of farms (37 in total), resulting in the simultaneous management of sun coffee (SC) and agroforestry coffee (AF) plots. We aimed (1) to identify factors that determine the farmers' selection of trees used in AF; (2) to describe the agroecological farms in transition; and (3) to perform an economic comparison between $\mathrm{AF}$ and SC. These objectives were addressed by combining data from botanical surveys in 1993/1994 and 2007 , by interviews with farmers and by detailed
\end{abstract}

H. N. de Souza - M. M. Pulleman

Department of Soil Quality, Wageningen University, P.O. Box 47, 6700 AA Wageningen, The Netherlands

Present Address:

H. N. de Souza $(\square)$

QMSW 4, lote 3, Apto 103, Setor Sudoeste, Brasília, DF 70.680-400, Brazil

e-mail: heltonnonato@yahoo.com.br

J. de Graaff

Land Degradation and Development Group, Wageningen

University, P.O. Box 47, 6700 AA Wageningen,

The Netherlands data on the production value and costs of labour and material inputs. The results showed considerable diversity in farming strategies and management among the farmers. Early adopters of AF had diversified towards production of different marketable products. The use of native trees in AF for this purpose, and for restoration of soil fertility (e.g., leguminous trees), had increased since the start of the experiments, while exotic tree species were eliminated. Over a period of 12 years AF was more profitable than SC due to the production of a diversity of agricultural goods, despite somewhat higher establishment costs. Other ecosystem services delivered by AF, such as biodiversity and cultural services are currently not valorized. Payment schemes for environmental services could further improve the economic benefits of AF for family farmers and alleviate establishment and learning costs.

Keywords Family agriculture $\cdot$ Coffee agroforestry · Productivity · Profitability · Ecosystem services

\section{Introduction}

Poverty and food security depend on the functions and services that local ecosystems supply (Sala and Montes 2007; SSNC 2008). However, the ability of ecosystems to secure human well-being has declined (MEA 2005). Increasing food production while 
reducing the dependency on fossil fuels, protecting wildlife species and enhancing environmental quality is an important challenge for today's society. As an alternative to the current model that focuses primarily on maximization of production of agricultural goods, new forms of agriculture that strengthen the delivery of multiple ecosystem services (ES) are being advocated (Lundberg and Moberg 2008; Brussaard et al. 2010). Interdisciplinary science, agricultural management interventions and institutional development at local and global scales are needed for ecological intensification of agricultural production (Perfecto and Vandermeer 2008; Carpenter et al. 2009), but many questions concerning the trade-offs between economic and ecological benefits remain.

In developing regions family agriculture is usually based on low external inputs and therefore strongly linked to internal resources and ecological processes (Sala and Montes 2007). For these conditions farming practices based on agroecological principles (i.e., optimizing the recycling of biomass and nutrients and enhancing species and genetic diversity and beneficial interactions among biological components) in order to maintain productivity with minimal use of agrochemicals and other external inputs have been promoted (Egoh et al. 2008; Schroth et al. 2009). Agroecological practices have been advocated as technologies that can simultaneously offer environmental, social and economic benefits to human beings and support the conservation of wildlife (Harvey et al. 2008; Ouinsavi and Sokpon 2008). In particular, agroforestry (AF) can combine production functions with biodiversity conservation by connecting fragments of remaining natural forest in the landscape (Buck et al. 2006).

In the past, coffee in most areas in Latin America was grown under the shade of a diverse tree canopy, providing various environmental benefits. In years of low coffee prices (and relatively high fertiliser prices) the trees were allowed to provide more shade, while in years of high coffee prices the shade trees were severely pruned, more fertilisers were applied and higher coffee production was obtained. With the introduction of new high yielding coffee varieties (mid of twentieth century) full sun coffee was more generally applied and this is particularly the case in Brazil. In more recent years renewed attention is paid to the environmental and biodiversity benefits of intercropping with multiple tree species and opportunities for certification of shade-coffee (Perfecto et al. 2005; Vaast et al. 2006).

However, on-farm studies of the economic aspects (including productivity, labour inputs and profitability) of AF are scarce and documentation of local knowledge on management strategies and tree selection is largely lacking (Molua 2005; Jose 2009). This type of knowledge would be crucial for scaling up AF coffee production and to inform agri-environmental and rural development policies (Molua 2005; Bennett and Balvanera 2007).

Our study focused on the Zona da Mata (ZM) region, located in the Atlantic Rainforest biodiversity hotspot (Myers et al. 2000) and characterized by the predominance of family farms. Sustainable agriculture is of vital importance for the ZM, where the side effects of the "green revolution" have caused severe environmental, agricultural and social problems (Ferrari 1996). Biodiversity loss in ZM is the result of a huge loss and fragmentation of forest cover of which only $12-14 \%$ remains today (Ribeiro et al. 2009; Teixeira et al. 2009). Participatory experimentation with agroecological principles has started in 1993, with the aim to enhance crop diversification, soil restoration, and biodiversity conservation on family farms. Furthermore, farmers, together with NGOs and university researchers started an agroecological transition process, making gradually adaptations on their farms converting them from the conventional approach to more ecologically based systems. As part of this experimentation AF coffee (Coffea arabica L.) systems have gradually been established on an increasing number of farms (37 in total; Souza et al. 2010, Cardoso et al. 2001).

Considering low external input systems and the relationships between biological components of an agroecosystem in terms of supplementarity, complementarity or competition (Conway 1987; Filius 1982), we hypothesized that AF systems have a higher productivity (here defined as the harvested products per unit of area) and profitability (defined as the gross margin per unit of area and per man day) than SC.

The aims of this study were to: (1) identify factors that determine the farmers' selection of trees in agroforestry systems; (2) describe the family farming systems in agroecological transition and (3) perform an economic comparison between coffee agroforestry systems and conventional coffee production systems. 


\section{Materials and methods}

Study site

The Zona da Mata (ZM) is located in the state of Minas Gerais (MG) and has a tropical highland climate. The average daily temperature is $18^{\circ} \mathrm{C}$ and the average precipitation is $1,500 \mathrm{~mm} \mathrm{year}^{-1}$, with 2-4 dry months. The slopes range from 20 to $75 \%$ and the altitude from 200 to $1,800 \mathrm{~m}$ (Golfari 1975). The main soil types are Oxisols, which are deeply weathered, well drained, acidic and poor in available nutrients (Cardoso et al. 2003). Around $18 \%$ of the population in ZM lives in the countryside, mainly on family farms (IBGE 2000). The average farm size is 18 ha and $91 \%$ of the farms has less than 100 ha (IBGE 2000). The characteristics of agricultural production in $\mathrm{ZM}$ are: long-term land use, small-scale production systems, and conventional agricultural practices, mainly for coffee production and cattle.

In the nineteenth century the rainforest was replaced by agriculture, mainly due to favorable climate and market conditions for coffee production (Dean 1995). Few forest fragments are conserved as forest reserves and coffee plantations extend to the top of the hills. Such deforestation has caused loss of biodiversity and soil erosion, leading to drastic loss of soil fertility (Dean 1995).

Conventional full-sun coffee (SC) is the predominant type of coffee production. However, family farmers that have participated in a participatory project that has run since 1993 (Cardoso et al. 2001), have changed at least part of their land from conventionally managed systems to systems based on agroecological principles. One of these systems is coffee agroforestry (AF), in which coffee plants are intercropped with trees, shrubs and herbaceous plants. The main functions of the trees are protection of the soil against erosion, recycling of nutrients and diversification of production. AF and SC systems are managed side-by-side on the same farm.

Selection of the farms and farming systems for this study

Within ZM there is a group of about 600 families, distributed over 20 municipalities, involved in agroecological transition through collaboration with local non-governmental organizations (NGOs), farmers' organizations and research institutes (Cardoso et al. 2001). These farms serve as a platform for knowledge exchange and study of the effects of agroecological practices on productivity and profitability of farming systems and of the environmental services provided. From these 600 families, a group of 100 families belong to a "Monitoring Program on the Sustainability of Agroecosystems" conducted by the NGO Centre of Technologies Alternatives of Zona da Mata (CTA$\mathrm{ZM}$ ) and partners (CTA-ZM 2006) with the aim to document changes in management practices on the farms. From these 100 families, three sets of farms were included in the study presented here (Table 1).

The first group was formed by those farms on which botanical surveys were carried out in AF plots in the early stage (1993/1994, 15 farms, group 1a) and approximately 13 years later (2007, 7 farms, group

Table 1 Study design for this paper considering the different groups of selected farmers, data sets used for each topic of investigation and the related objectives

\begin{tabular}{|c|c|c|c|c|}
\hline Group & $\begin{array}{l}\text { Number of } \\
\text { family farms }\end{array}$ & Data used & Topic of interest & Objective \\
\hline $1^{\mathrm{a}}$ & 15 & Botanical survey conducted in: $1993 / 94$ & \multirow{2}{*}{$\begin{array}{l}\text { Determinant factors for the selection } \\
\text { of trees to improve performance of } \\
\text { regional agroforests }\end{array}$} & \multirow[t]{2}{*}{1} \\
\hline $1^{\mathrm{b}}$ & 7 & 2007 & & \\
\hline 2 & 6 & $\begin{array}{l}\text { Farming activities, management, farm layout, inputs } \\
\text { and outputs obtained through participatory } \\
\text { techniques (interviews, flow diagram, maps) }\end{array}$ & $\begin{array}{l}\text { Description of family farms in } \\
\text { agroecological transition }\end{array}$ & 2 \\
\hline 3 & 3 & $\begin{array}{l}\text { Coffee production, labour (demand }+ \text { costs), } \\
\text { sales, spending }\end{array}$ & $\begin{array}{l}\text { Economic comparison between } \\
\text { agroforestry and conventional systems }\end{array}$ & 2 and 3 \\
\hline
\end{tabular}

\footnotetext{
${ }^{a}$ Regional references of coffee agroforestry experiments established at initial phase

b Best regional performers of coffee agroforestry experiments at later stage of experimentation; in this group of 7, two farms of the group of 15 are included
} 
1b). Although the overlap between the two groups is only two farms, the use of two sets of representative farms allows for the interpretation of changes in composition of coffee AF, by considering the existing data on tree species and their uses by local farmers over a long period of experimentation (objective 1).

A second group of farmers implemented agroecological practices in the period 2003-2005 and was composed of 6 families (Farms 1-6; Fig. 1), which volunteered (one family per municipality) to participate in a specific activity inserted in the monitoring program mentioned above, which should reveal "indicators of sustainability".

A third group was formed by three families (Farms A1, A2 and D1; Fig. 1). These belonged to the early adopters of AF in ZM and started in 1993/1994 (Souza 2006). Information on farming practices and management from the second and third group ( 9 farms) were used to address objective 2 .

For the economic comparison of AF versus SC systems (objective 3) we focused on the third group, the early adopters. These three farms maintained parallel long-term AF and SC experiments within each farm and were comparable in terms of slope and age of the coffee plants. These three families were living under similar social and economic conditions.

\section{Data collection}

\section{Changes in tree composition}

Two botanical studies were used to assess the changes that occurred in tree family composition across the AFs established between 1993 and 2007. Franco (2000) conducted the botanical survey in 15 of the 37 initial AF experiments established in 1993-1994 and Siqueira (2008) studied the 7 best developed AF plots, as suggested by local farmers in 2007. The farms A1 and A2 were included in both surveys. Information on uses of trees was obtained through a participatory appraisal among farmers.

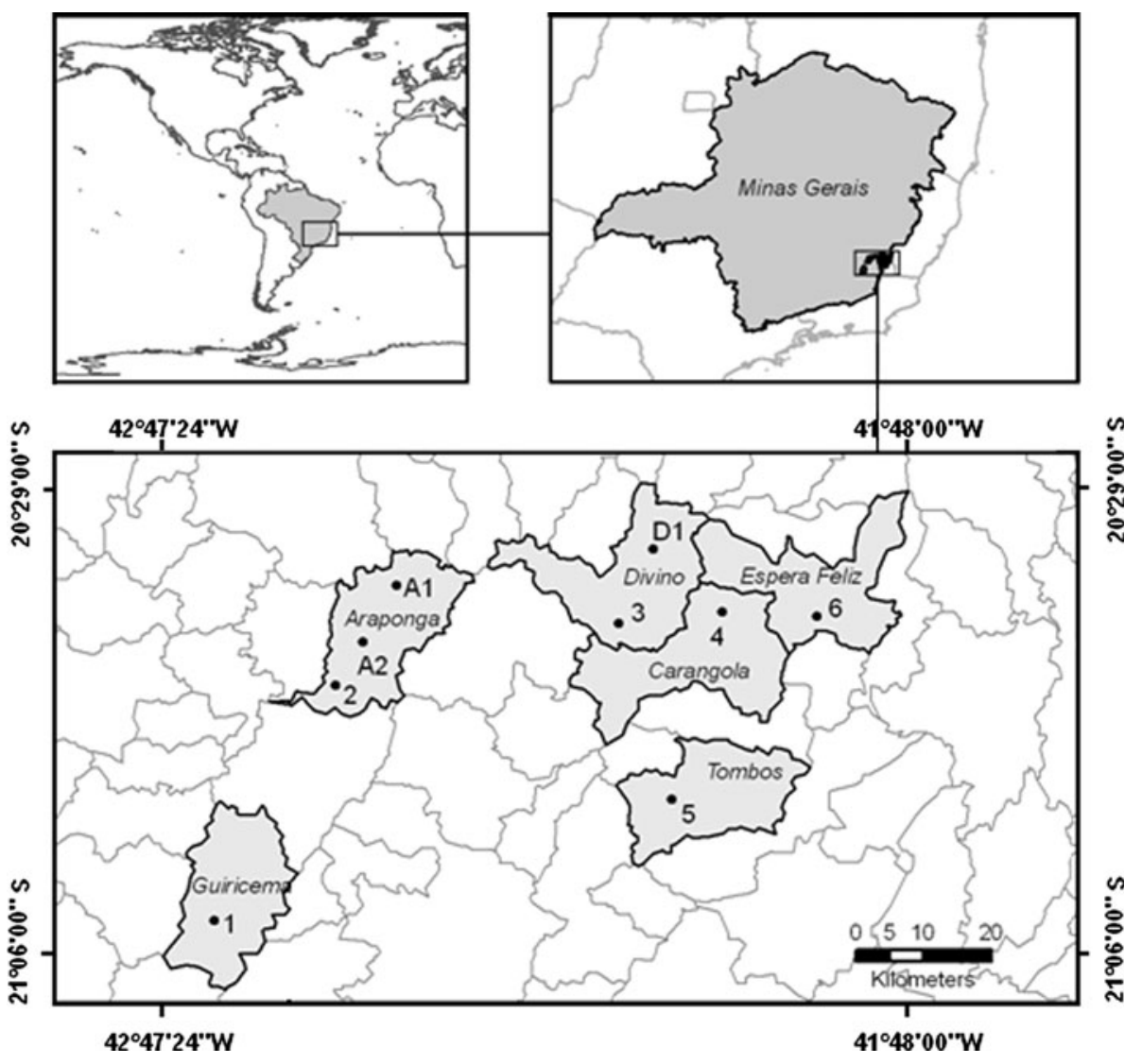

Fig. 1 Location of the selected farms in six municipalities of the Zona da Mata (ZM), Minas Gerais state, Brazil 


\section{Farm characterization}

The six farmers of group 2 recorded the data on consumption, production, income, farm layout and subsystems, crops, inputs, outputs and the annual calendar of farming activities and shared them during several meetings held between 2005 and 2006. The three farms of group 3 were visited in 2008 to obtain the same information. During the visits the flow diagram technique (Geilfus 2000) was used. The flow diagram provides an evaluation of all inputs and outputs of the agroecosystems, including both the material inputs and services and the products produced. It also allows the identification of the links of farming systems with the other agroecosystems of the property (Geilfus 2000). The diagrams were drawn by the families during the interviews. This was first done for each individual subsystem, and thereafter for the whole farm.

The nine farmers of groups 2 and 3 provided the results of the last soil analysis for the coffee plots (SC and AF) carried out in the labs of the Soil and Plant Nutrition Department of Federal University of Viçosa in 2005/2007. The range of soil characteristics of the farms is presented in Table 2.

The three farms of group 3 fell within the range of soil characteristics found for group 2 (Table 2). Group 3 (early adopters) presented less variation in nutrient and organic matter content and generally higher values than group 1 (Table 2).

\section{Analysis of productivity and profitability}

During the visits of farms A1, A2 and D1 in February and March 2008, more detailed information used for the economic comparison (objective 3) was also collected. The annual average production of the most important products over 3 years (2005-2007) was calculated based on the farmers' individual notes and the number of trees existing in each AF system was counted. Elevation and slope of the farms were measured with GPS and clinometers.

The steps used for the analysis of production costs are based on Duarte et al. (2004), in which the Production value $\mathrm{A}$ minus the costs $(\mathrm{B}+\mathrm{C}+\mathrm{D}+$ $\mathrm{E}+\mathrm{F}+\mathrm{G}$ ) is equal to Gross Margin I. Below more details are given for the respective items A until J:

A. Total production values: the production values were obtained by considering all marketable products produced during 1 year. The prices of these products were verified in the local market of Araponga and Divino during February and March 2008.

B. Annuities of establishment costs were calculated based on the activities (person days) and materials (material costs) required to establish the different coffee systems. One farmer belonging to the first group of 6 farms had accurately documented all activities related to the establishment of his SC and AF systems. We used his data to calculate the establishment costs over a period of 3 years. Based on the information provided by the farmers we set the length of the production cycle at 12 years for both systems.

C. Labour for cropping covers the annual activities required for the cash crop (coffee), other crops or products, and the production of compost. The prevalent daily wage rate in the region is $\mathrm{R} \$ 20.00$ a day or US\$ 11.00 dollar (March 2010).

D. Intermediate consumption included all expenses for external inputs not produced on the farm (e.g., fertilizers, lime, bio-fertilizers, compost, bags, and boxes).

E. Processing costs were the total cost of postharvest activities for all products on the farm. The costs of coffee drying on the ground was

Table 2 Range of soil characteristics for selected farms in Zona da Mata, Brazil

\begin{tabular}{|c|c|c|c|c|c|c|c|c|c|}
\hline Farms & Period & $\begin{array}{l}\mathrm{pH}_{\mathrm{H}_{2} \mathrm{O}} \\
(1: 2.5)\end{array}$ & $\begin{array}{l}\mathrm{P} \\
\left(\mathrm{cmol}_{\mathrm{c}} \mathrm{dm}^{-3}\right)\end{array}$ & $\begin{array}{l}\mathrm{K} \\
\left(\mathrm{cmol}_{\mathrm{c}} \mathrm{dm}^{-3}\right)\end{array}$ & $\begin{array}{l}\mathrm{Ca} \\
\left(\mathrm{mg} \mathrm{dm}{ }^{-3}\right)\end{array}$ & $\begin{array}{l}\mathrm{Mg} \\
\left(\mathrm{mg} \mathrm{dm}{ }^{-3}\right)\end{array}$ & $\begin{array}{l}\mathrm{CEC}^{1} \\
\left(\mathrm{mg} \mathrm{dm}^{-3}\right)\end{array}$ & $\begin{array}{l}\mathrm{B} \mathrm{Sat}^{2} \\
(\%)\end{array}$ & $\begin{array}{l}\mathrm{OM}^{3} \\
(\%)\end{array}$ \\
\hline Group $2^{\mathrm{a}}$ & $2005 / 6$ & 4.9-6.6. & $0.4-7.6$ & $29-161$ & $0.3-5.4$ & $0.2-1.7$ & $7.2-19.0$ & $6.3-85.0$ & $2.7-5.3$ \\
\hline Group $3^{\mathrm{b}}$ & 2007 & $5.6-6.0$ & $2.7-4.8$ & 89-164 & $2.8-5.7$ & $0.6-1.5$ & $3.6-7.6$ & $30.0-76.0$ & $4.3-5.7$ \\
\hline
\end{tabular}

Codes: $C E C$ cation exchange capacity, base saturation, $O M$ organic matter

a Farms in agroecological transition (1-6)

b Farms of early adopters (A1, A2, D1) 
calculated at US\$ $1.67 \mathrm{bag}^{-1}$ (one bag $=60 \mathrm{~kg}$ ) for coffee in the early processing stages called "café em coco" (Bliska et al. 2009).

F. Overheads were considered $2.5 \%$ of intermediate consumption following Bliska et al. (2009).

G. Interest on circulating capital was defined as $12 \%$ of the sum of intermediate consumption and overhead costs (Bliska et al. 2009).

H. Total person days is the time spent (including temporary workers) on farming activities.

Gross margin (GM) was calculated by deducting the variable costs and also some fixed costs $(\mathrm{B}+\mathrm{C}+\mathrm{D}+\mathrm{E}+\mathrm{F}+\mathrm{G})$ from the total production value (A). A distinction is made between "GM including labour" (I), whereby labour costs are also deducted and "GM excluding labour" (J) whereby labour costs are not deducted. The gross margin per person day is obtained by dividing "GM excluding labour", by the total number of person days. This can be compared with the prevalent wage rate.

\section{Results}

Tree composition and tree selection criteria at two different stages of implementation

During implementation of the initial AF experiments, the farmers together with a local NGO and university researchers, focused on the following factors when selecting trees for the AF systems: (a) stability/risk alleviation, (b) avoiding nutrient competition, and (c) maintaining or increasing coffee production
(Souza 2006). Changes in tree composition over time, since the start of the on-farm AF experiments in the early 1990s (Franco 2000) until 2008 (Siqueira 2008) are shown in Fig. 2. The respective uses of each tree family are indicated at the bottom of the graph and are based on the information provided by the farmers during semi-structured interviews (Fig. 2). Several exotic tree species that were found in the AF systems in 1993/1994 were not present in the AF systems monitored in 2007 (e.g., Casuarinaceae, Ebenacea, Myrsinaceae, Pinacea and Caprifoliacea) (Fig. 2). Farmers reported that they had been eliminated because of their different requirements in terms of climate and soil conditions that led to increased competition with, or damage to, coffee plants. Tree families that provide multiple products, such as food, wood, green manure, medicine and other products (e.g., fibre, oil, seeds), were kept or added (e.g., Bignoniaceae, Rutacea, Myrtaceae, and Euphorbiaceae). Local availability and market opportunities are determining factors for selecting those trees with multiple uses.

The initial AF experiments on 15 family farms (group 1a) started with a minimum of 2 and a maximum of 72 tree species per AF plot, belonging to a total of 34 different tree families (Fig. 2). This wide range in the number of tree species reflects a high diversity of approaches by different groups of farmers due to the high uncertainty resulting from lack of experience. One group decided to start with planting few tree species to avoid risks. In the opposite extreme there was another group of farmers that decided to experiment with a large pool of tree species to be intercropped with coffee. Thirteen years later 7 family
Fig. 2 The proportional distribution and the uses of trees in AF systems as obtained from 15 and 7 farms, surveyed in 1993-1994 and 2007, respectively

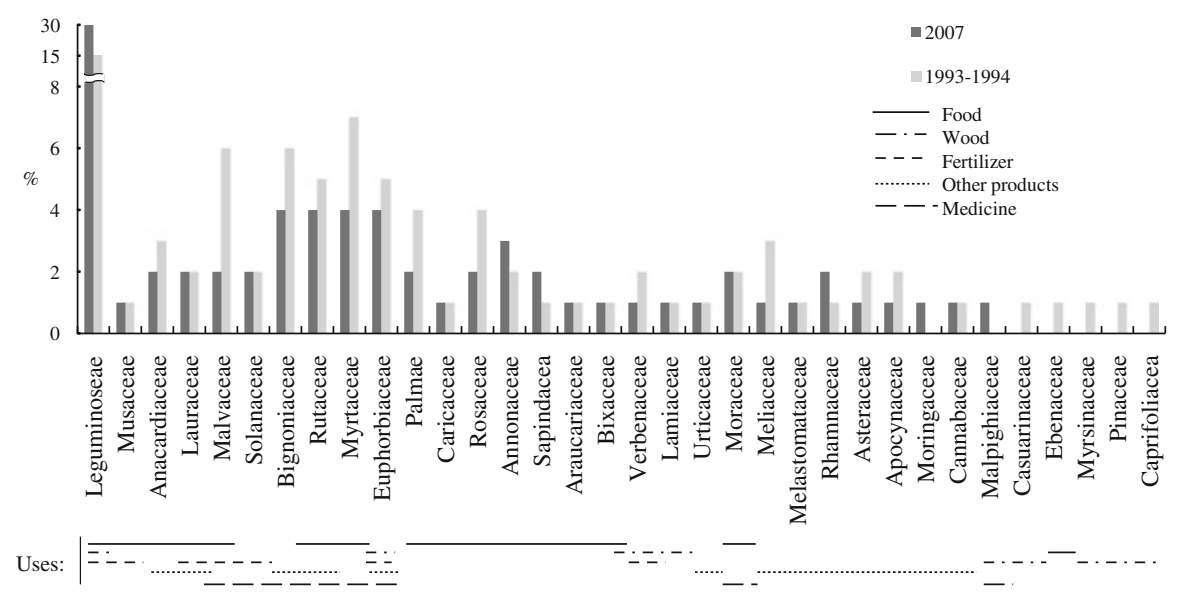


farms (group 1b) reported different criteria for selecting trees than those initially defined at the start of the project. Selected trees included then species that (a) are compatible with the coffee crop; (b) produce a good amount of biomass; (c) are soft and easy to manage (e.g., cutting, pruning, transporting), and (d) provide extra products such as food and animal feed, or (e) stimulate wildlife, as reported during the interviews.

General characterization of the farms and their coffee systems

A compilation of the individual flow diagrams (not shown) that was obtained for each of the 9 family farms of groups 2 and 3 demonstrated that all of them had diversified their farms as part of the agroecological transition, with the objective to make the different components of subsystems more closely connected and mutually supportive to reduce the need for external inputs. These 9 families represented a range of different farm settings in family agriculture in the ZM. The farm size ranged from 6 to 90 ha. The number of family members, indicative for labour availability, ranged from 2 to 7 . Six families were land owners and three were tenants. The total area of coffee cultivation on the different farms ranged from 1.5 to 9.5 ha, corresponding to $4-47 \%$ of the total farm area. The density of coffee plants ranged from 2,310 to 7,500 ha ${ }^{-1}$ in SC and from 1,785 to 5,333 ha ${ }^{-1}$ in AF. The land owners, especially the early adopters of AF, had a more diversified farm in terms of the number of commercialized products and the presence of own forest (Table 3).

Coffee was the main cash crop and different types of coffee plots were present at all the farms. On 7 out of 9 farms, the area under SC was higher (ranging from 0.9 to 7.9 ha) than the area under AF on the same farm (0.3-2.6 ha). Coffee planting density was distinctly higher in $\mathrm{SC}$ than in AF on four of the farms (farms 2, 5,6 and A2), more or less similar on the other four farms (farms 1, 4, A1 and D1) and lower in SC than in $\mathrm{AF}$ on farm 3. The number of commercialized products and the presence of forest on the farm varied depending on land tenure. Based on the farms considered in our study, coffee production (parched) under AF ranged from 120 to $1,644 \mathrm{~kg} \mathrm{ha}^{-1}$ and under SC (based only on the early adopters' farms) it ranged from 1,320 to $1,602 \mathrm{~kg} \mathrm{ha}^{-1}$. For Farm 1 there was no
AF coffee production in 2005 because that was the first year in which coffee was planted.

A large variety of crops was produced on each farm in AF areas. Food, firewood, water and construction materials are the most common needs for the family. Although such diversity contributes to local agrobiodiversity, it also increases labour intensity in the beginning, which was indicated as a constraint by 6 out of 9 farmers.

Forest within the farms is also called "reserve", following the Brazilian environmental law. However, wood and non-wood products can be harvested for family consumption only (e.g., honey, seed, medicines and fibre). Together with AF as a subsystem they represented the main source of wood for construction (Table 3).

Management of SC and AF coffee systems

More detailed information on coffee management was obtained for the three farms of group 3 (Table 4). On a yearly basis, the management activities could be divided into three main periods. From January to April, the activities included the first sowing of some annual crops, weeding, fertilizer application, tillage, and trimming. The harvesting of beans, maize, and cassava is done from May to July. From May till September, the main activities are to soil preparation, crop management (routine), foliar fertilization and the second sowing of beans and maize.

In $\mathrm{AF}$ the spontaneous vegetation is kept or trimmed, no pesticides or herbicides are used and limestone is applied biannually. The use, type and quantity of fertilizers depend on whether the AF coffee is certified for organic production or not. Family members do most of the field operations in the AF systems. The SC systems do not have trees shading the coffee. In this type of system liming is done biannually, fertilizers are applied annually and herbicides/ pesticides are used when considered necessary. Some farms apply tillage and some farms do not. Some farmers intercrop the coffee with herbaceous plants (in few cases even with annual crops). It is common to employ temporary workers for field operations in the SC systems. Soil preparation includes limestone broadcasting and manure application. In some cases manual tillage is used, especially when maize is cultivated. All coffee systems are biannually limed 


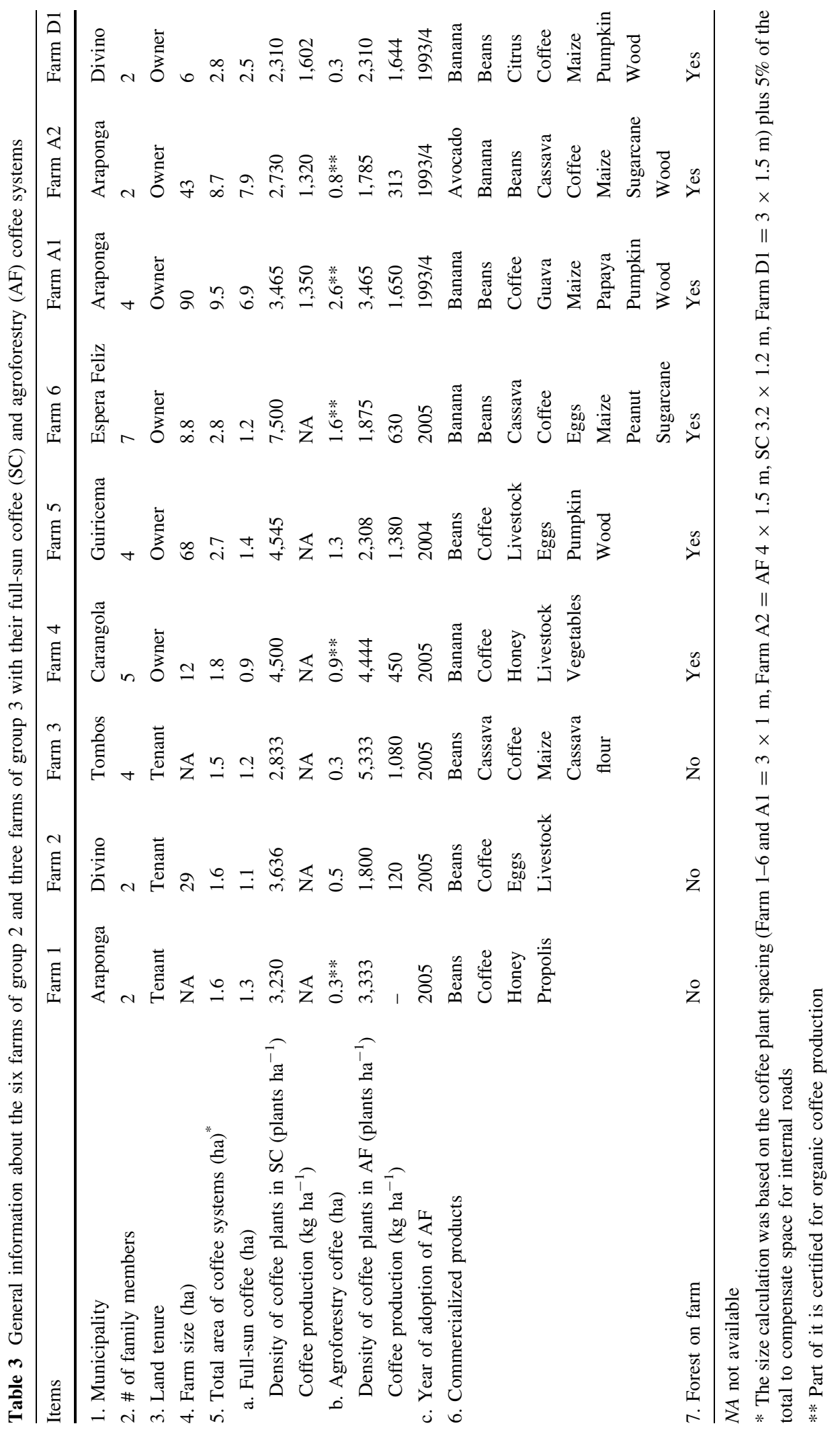




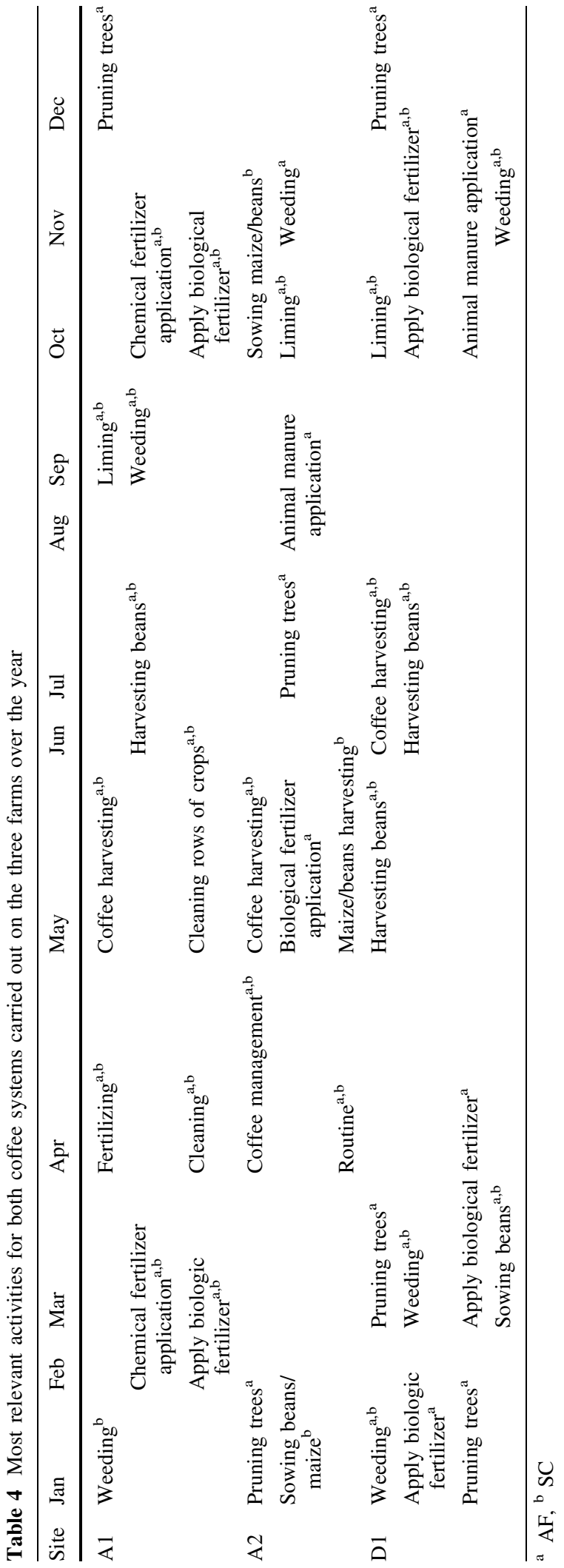

and annually fertilized. The farmers spray homemade liquid compost called "supermagro", as biological fertilizer in AF at least twice a year. Spontaneous vegetation in the coffee field is weeded at least twice per year, mainly in the period November to February, and residues are left on the soil surface. The pruning of the trees is done from December to March on all farms, but on farm A2 the bottom branches of the trees are also pruned in July.

Characteristics of selected SC and AF coffee systems used for economic evaluation

The specific characteristics of the AF and SC coffee systems of group 3 farms are shown in Table 5. The systems in each farm were established at similar elevation (ranging from $1,040 \mathrm{~m}$ at farm A2 to $1,160 \mathrm{~m}$ at farm D1). Slopes were steeper on farm A2 (75\%) than on A1 and D1 (approximately 34\%). The size of the coffee systems ranged from 0.45 to 0.77 ha for SC and $0.15-0.72$ ha for AF.

The density of coffee plants was the same for both systems in the case of A1 and D1. In A2 the AF system had a lower planting density $\left(1,700\right.$ coffee plants ha $\left.{ }^{-1}\right)$ than the SC $\left(2,600\right.$ coffee plants $\left.\mathrm{ha}^{-1}\right)$ which resulted in $76 \%$ higher production per unit area for SC than for AF. In addition to this, the farmer stated that the location, where the AF was established, was a "cooler area" that always affected negatively the production performance. For this farmer, the main goal was to rehabilitate the area by controlling soil erosion. Any extra coffee production obtained from that area would be considered an advantage. On the farms A1 and D1 the coffee production per hectare was respectively 18 and 3\% higher for AF than for SC (Table 5).

The AF systems contained on average 335 trees $\mathrm{ha}^{-1}$, but they differed in taxonomic richness (Table 5) and composition, which is related to the history of land use and to the requirements of the farms. On farm A1 the area where AF and SC were implemented had been degraded after several years of rice cultivation, and coffee stopped to produce. In the beginning, soil was covered by grass species and the tree species Hovenia dulcis (uva-do-japão), Glandulosa colubrine (sobrasil), Inga sessilis and Inga subnuda were interplanted randomly with the coffee. On farm A2 the AF system was introduced to halt the advanced erosion process, which had removed the top soil and deposited the soil material to the lowest part of 
Table 5 Characterization of the agroforestry and full-sun coffee systems of the three early adopters in the Zona da Mata, Brazil

\begin{tabular}{|c|c|c|c|c|c|c|c|c|}
\hline \multirow[t]{2}{*}{ Systems } & \multirow[t]{2}{*}{ Elevation (m) } & \multirow[t]{2}{*}{ Slope (\%) } & \multirow[t]{2}{*}{ Area (ha) } & \multicolumn{4}{|l|}{ Coffee plantation } & \multirow{2}{*}{$\begin{array}{l}\text { Trees } \\
(\# / \text { ha })\end{array}$} \\
\hline & & & & Plants (\# ha ${ }^{-1}$ ) & Spacing $(\mathrm{m})$ & Age (year) & $\begin{array}{l}\text { Production* } \\
\left(\mathrm{kg} \mathrm{ha}^{-1}\right)\end{array}$ & \\
\hline AFA1 & 1,062 & 33 & 0.15 & 3,300 & $3.0 \times 1.0$ & $12-14$ & 1,650 & 380 \\
\hline SCA1 & & & 0.75 & 3,300 & $3.0 \times 1.0$ & $12-14$ & 1,350 & 0 \\
\hline AFA2 & 1,040 & 75 & 0.72 & 1,700 & $4.0 \times 1.5$ & $12-14$ & 317 & 370 \\
\hline SCA2 & & & 0.77 & 2,600 & $3.2 \times 1.2$ & $12-14$ & 1,320 & 0 \\
\hline AFD1 & 1,160 & 35 & 0.27 & 2,200 & $3.0 \times 1.5$ & $10-14$ & 1,644 & 257 \\
\hline SCD1 & & & 0.45 & 2,200 & $3.0 \times 1.5$ & $10-14$ & 1,600 & 0 \\
\hline
\end{tabular}

Codes: $A F$ agroforestry, $S C$ full-sun coffee systems, $A$ Araponga, $D$ Divino

* Considered the average over 3 years $(2007,2008$ and 2009)

the farm where it had damaged the roads and farm buildings. The farmer planted some trees belonging to a pioneer succession and several fruit species, mostly avocado (Persea americana). The farmer has harvested bananas, oranges, avocados, sugarcane and pumpkin from the AF. This system is converted into an organic system and the coffee plants have been rejuvenated once, in the beginning of the experiment. The system has a low density of coffee plants compared to the other two farms. Chemical fertilizers were not applied in this system.

The farmer of D1 planted some pioneer trees in his $\mathrm{AF}$ system and there were already some mature trees from secondary succession, such as Zeyheria tuberculosa (ipê-preto), Tabebuia sp. (ipê-amarelo) and Vitex montevidensis (maria-preta). This area was originally an abandoned pasture. Bananas, oranges and avocados have been harvested from the AF. The trees also supply wood for construction, firewood, fencing and animal feed.

Production values and gross margins in AF and SC systems

The total production value was higher for all AFs (ranging from US\$ 4,976 to 6,281 ha year $^{-1}$ ) in comparison to all SCs (ranging from US\$ 3,534 to $4,284 \mathrm{ha}^{-1}$ year $^{-1}$ ) (Table 6). The production value for AF-D1 was about $20 \%$ higher than for AF-A1 and AF-A2. For SC-D1 the production value was about $17 \%$ higher compared to SC-A1 and SC-A2.

In AF-A2 other products than coffee, including banana, papaya, pumpkin, citrus, wood, and guava, made up $73 \%$ of the total production value. Banana, citrus, pumpkin, wood, and organic compost represented $30 \%$ of the total production value in AF-D1, whereas in AF-A1 the products banana, wood, avocado, cassava, sugarcane and organic compost represent only $14 \%$ of total value (Table 6).

The annuity of establishment costs was on average $17 \%$ higher for the AFs than for the SCs due to the increased labour for other crops (Table 6). Labour is the most expensive factor during this phase contributing on average $58 \%$ of establishment costs in both systems, over the first 3 years. The establishment costs of other crops are on average $11 \%$ of the total establishment costs (data not shown). The labour required for annual cropping was higher for $\mathrm{AF}$ than for SC, varying from 136 to 202 person days $\mathrm{ha}^{-1}$ year $^{-1}$ in AF, and from 99 to 134 person days ha ${ }^{-1}$ year $^{-1}$ for SC. The intermediate consumption values largely depended on the management, arrangement and level of external inputs of the farming systems (e.g., chemical fertilizers, lime, liquid compost, fuel and electricity cost). While AF-A1 (US\$ $641 \mathrm{ha}^{-1}$ year $^{-1}$ ), SC-A1 (US\$ $631 \mathrm{ha}^{-1}$ year $^{-1}$ ), AF-D1 (US\$ $851 \mathrm{ha}^{-1} \mathrm{year}^{-1}$ ) and SC-D1 (US\$ $841 \mathrm{ha}^{-1}$ year $^{-1}$ ) have quite similar expenses in both systems, in AF-A2 the intermediate consumption value is much lower (US\$ $158 \mathrm{ha}^{-1}$ year $^{-1}$ ) than in SC-A2 (US\$ $522 \mathrm{ha}^{-1}$ year $^{-1}$ ), mainly because no chemical fertilizers are used in AF-A2.

Regarding the processing costs, more labour is required for coffee than for other products (e.g., drying, bagging, post harvest preparation, transport). The costs of total material inputs depended on the type of crops, frequency of cultivation and care needed. The values were higher for AF on all three farms. 


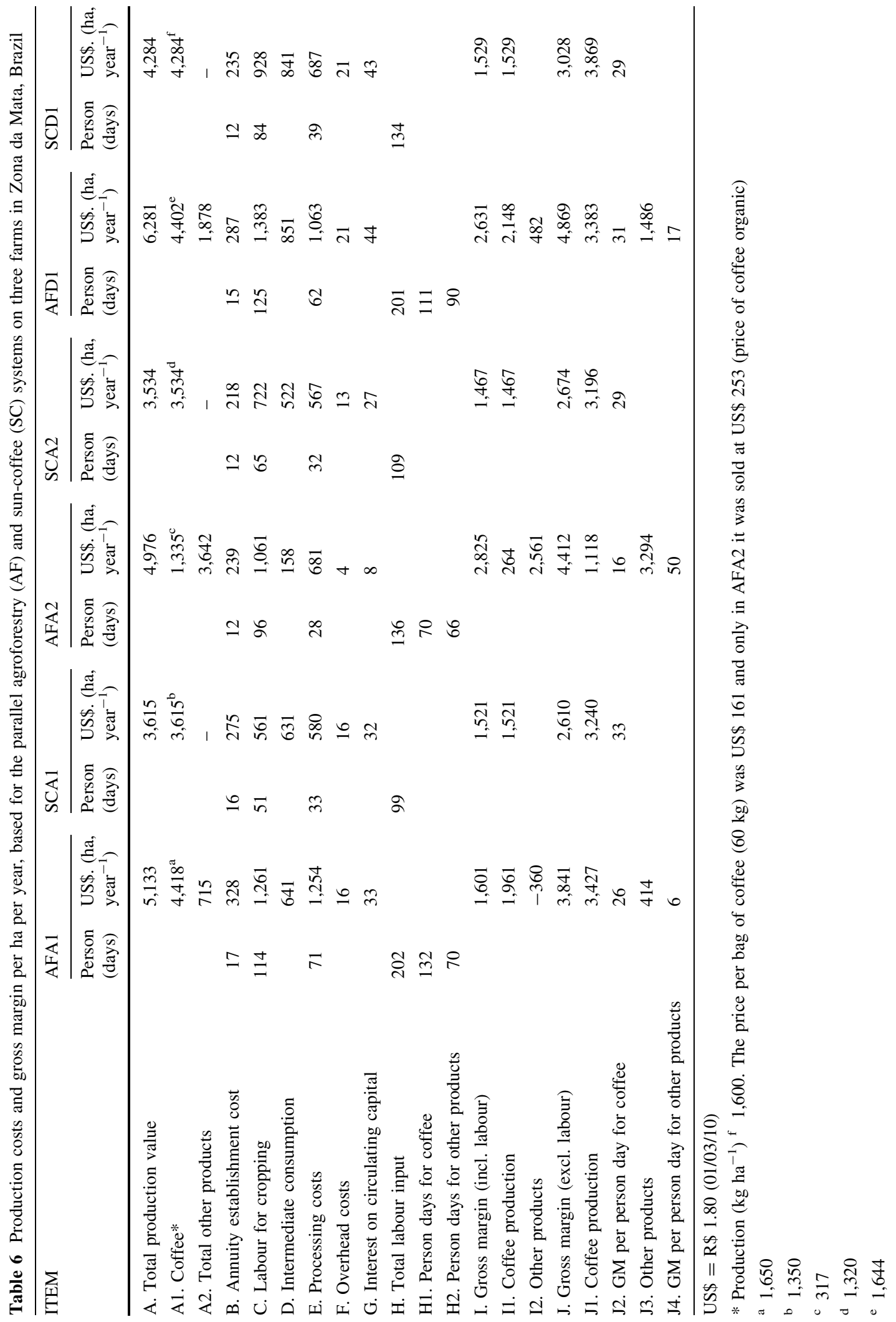


They were considerably higher in AF-A1 (US\$ $1,254 \mathrm{ha}^{-1}$ year $^{-1}$ ) than in SC-A1 (US\$ 580) $\mathrm{ha}^{-1}$ year $^{-1}$ and in AF-D1 (US\$ 1,063 ha year $^{-1}$ ) than in SC-D1 (US\$ $687 \mathrm{ha}^{-1}$ year $^{-1}$ ) and somewhat higher in AF-A2 (US\$ $681 \mathrm{ha}^{-1}$ year $^{-1}$ ) than in SC-A2 (US\$ 567). Most of the products intercropped with the coffee cannot be stored and demand immediate processing when harvested (e.g., pumpkins, banana, green maize, papaya).

Despite the higher establishment, labour and processing costs for $\mathrm{AF}$ in comparison to $\mathrm{SC}$, the gross margin, both including and excluding labour, was higher for AF than for SC on all three farms (Table 6) thanks to the higher overall production value of $\mathrm{AF}$. The gross margin per person day for coffee was for all systems higher than the prevalent wage rate of US\$ 11.00. The exception was the value of the gross margin per person day for other products in AF-A1 that has a lower value than the prevalent wage rate.

\section{Discussion}

Farmers' selection of trees in AF systems

For the majority of the farmers intercropping trees and coffee was quite a challenge initially due to lack of experience with $\mathrm{AF}$ in the region and the difficulties to select the suitable trees among many species available in the Brazilian Rainforest biome. By comparing tree species composition on farms between 1993-94 (group 1a) and 2007 (group 1b) we obtained insight in the developments of tree selection criteria with time. Although Group 1b only included two farms of group 1a, and a pure quantitative comparison is not possible, it is important to note that the 7 farms of group 1 b, surveyed in 2008, were the "best performers" in the view of the farmers. Hence, in a general sense, the difference between the two groups reflects the selection of the tree families most compatible with regional coffee AF and other farmers' needs.

The use of leguminous tree species had clearly increased between 1993-94 and 2007, whereas the contribution of exotic trees had decreased (Fig. 2). It is widely known that leguminous species are very beneficial to tropical agroecosystems because of the low natural soil fertility. A study carried out by Duarte (2007) in AF systems in ZM showed that Senna macranthera, Erythrina verna and Inga subnuda are $\mathrm{N}$ fixers and contribute to the fertilization of crops by supplying on average $0.4 \mathrm{~kg} \mathrm{year}^{-1}$ of $\mathrm{N}$ per tree. In addition S. macranthera and I. subnuda produced the highest amount of leaf litter, thereby returning on average $52 \mathrm{~kg}$ tree year ${ }^{-1}$ of organic material to the soil. Jaramillo-Botero (2007) showed that the leguminous tree species $S$. macranthera, planted at a distance of 3-5 $\mathrm{m}$ from coffee trees had a positive effect on coffee production at the family farm in Araponga.

The plant composition in the AFs on the three farms studied for the economic analysis was correlated with farmers' preferences based on market accessibility and environmental needs (e.g., soil fertility). The results point out the need for further investigations on a wide range of leguminous tree species to match farmers' needs. This concerns mainly $\mathrm{N}$ fixing species. For example, farmers could select trees to increase $\mathrm{N}$ fixation among several available leguminous tree species. Such decision would help to increase the number of plants which contribute to $\mathrm{N}$ inputs, and at same time provide other uses for family consumption. It would also lead to further diversification in terms of tree species composition thereby enhancing the conservation of tree diversity in the landscape.

Family farming systems in agroecological transition

The characteristics of the farms studied here were in line with the most common regional family size (4-6 members), and land tenure characteristics reported by Miranda (2002). These factors have a strong influence on farm management decisions and arrangements of the land and on which farming systems are adopted (Klingen 2009; Miranda 2002). Diversified farms and more connected subsystems took part of the agroecological transition aiming to reduce the need for external inputs. The outputs (e.g., crop residues, dung) of one farm component were used as an input for another component. In contrast, conventional coffee producers usually do not pay attention to interactions among subsystems, once they use chemical fertilizer. Ethnobotanical studies conducted on seven AF plots in the same region have identified more than nine different uses of trees on farms, including construction materials, firewood and medicines (Siqueira 2008; Fernandes 2007). Farmers reported that the productivity of forest and AF systems depended on soil 
conditions and their age, which influence the arrangement, composition and structure of these ecosystems. They were aware that time is needed to achieve best results for soil improvements as well as farm performance. That was the reason why farmers kept both AF and SC on the farm, so that they can make changes gradually.

Productivity and economics of AF and SC systems

Reflect on the coffee yields which were very variable depending on farmers strategies and preferences. Each farmer manages his own farm to keep productivity and profitability of the implemented systems, and therefore is a source of information for family agriculture. For farm A1, labour requirements were less for SC than for AF. The farmer preferred to focus on the coffee, because of the higher returns on investment and to invest less time in the production of other products. In D1, although it is diversified and produces several other products (e.g., wood, banana, citrus, beans), the total production costs are higher compared to the others. However, on the third farm (A2) the management approach adopted shows that long term planning is needed in order to deal with more complex agroecosystems. The farmer has been able to get his area certified according to an organic standard that allows him to get a higher price for his coffee production (60\% higher). The diversification of products (avocados, bananas, cassava, wood, sugarcane) together with the strategy of farm-gate sales guarantees the farm stability during the period of reestablishment of the coffee production (after rejuvenation). For example, on farm A2, P. americana (Lauracea) produced on average $120 \mathrm{~kg}_{\text {year }}{ }^{-1}$ of avocado fruits per tree, thereby generating extra income for the family.

Considering production, all cases show a higher return to labour than the wage rate of US\$ 11.00 per person day. The gross margin per person day for coffee production obtained from SC in A1 and A2 (US\$ 33 and US\$ 29 person day ${ }^{-1}$, respectively) were higher than in AF (US\$ 26 and US\$ 16 person day ${ }^{-1}$, respectively). Some reasons for this could be that more labour was required for investments in coffee production than in other products, that the products selected were less accepted in the regional market (e.g., guava, pumpkin) or that they had higher processing costs, reducing the revenues. The contrary was observed in
D1 where the gross margin in AF (US\$ 31 person day $^{-1}$ ) was higher compared to SC (US\$ 29 person $\mathrm{day}^{-1}$ ). A possible explanation for the higher production could be the fact that AF-D1 has received more organic fertilizers (cow manure, castor bean cake, residues of leguminous species, biofertilizer and cattle urine), as mentioned by the farmer. Higher soil fertility was found at this farm that may contribute to a better production in both coffee systems. In addition, AF-D1 had a lower density of intercropped trees and higher diversity of tree families. Furthermore this is the smallest farm, so more time could be spent on the other crops.

For risk reduction reasons it is advisable to have both coffee systems side by side, at least during the transitional/learning phase.

Ecosystem services and economic incentives

In current economic models, many ecosystem services are considered economic externalities by farmers, economists and society, and tend to be under-valued (Pagiola et al. 2007; Alavalapati et al. 2004). Farmers receive payments for the food, fiber and other goods they produce (categorized as provisioning services), but the real value of other ecosystem services (e.g., supporting, cultural, regulating services) is generally ignored or underestimated (Costanza 2000). For instance, a survey conducted in the surroundings of the Brigadeiro State Park showed that $1.44 \mathrm{~m}^{3} / \mathrm{month}$ of firewood is consumed per family (Casali et al. 1997). Extrapolating this value to over 600 families involved in agroecological transition in $\mathrm{ZM}$, this could save $10,368 \mathrm{~m}^{3}$ year $^{-1}$, or 5,456 trees a year from being cut elsewhere, outside these farms (12 years old tree: $6.0 \times 0.30 \mathrm{~m}$, calculated according to Brown et al. (1989)). In a study performed on agroforestry systems in Peru and Guatemala the consumption and sale of all non-coffee products accounted for 20-30\% of the total value obtained from the agroforestry system and tree species that provided good fuel wood and construction materials were preferred by the farmers (Rice 2008). Among other ecosystem benefits is the reduction of soil and nutrient losses due to erosion (Franco et al. 2002), which contribute to a better water quality and quantity and Carbon sequestration to mitigate global climate change (Montagnini and Nair 2004). 
With the advent of economic instruments such as Payment for Ecosystem Services (PES), these benefits could be internalized, ensuring that those services are taken into account monetarily (Pascual and Perrings 2007; Zbinden and Lee 2005). Most PES schemes focus on carbon sequestration, biodiversity and/or soil and water conservation (Pagiola et al. 2007). Some examples in Latin American countries are The Western Altiplano Natural Resources Management Project (Guatemala), a GEF-financed project (Venezuela), Hydrological Environmental Services program and BioCarbon Fund (Mexico), The Ecomarkets Project and biodiversity conservation (Costa Rica) and others under preparation (Dominican Republic, Ecuador, and El Salvador) (Pagiola et al. 2004).

According to PES schemes currently available in Brazil, groups of farmers could receive additional income when adopting soil and water conservation practices on their farms, up to a maximum of US\$ 55.6 ha year $^{-1}$ (Chaves et al. 2004). These payments can be received for a maximum period of 3 years, which coincides with the period of additional expenses on (annuity of) establishment costs in AF when compared to SC. In addition, the time between AF adoption and reaping the benefits from the diversification can take several years. Ricci and Oliveira (2007) argue that in the first 3 years after adoption of AF farm income is substantially lower due to high costs, intensive labour, and the fact that trees do not yet provide any commercial benefits. The farmers that have adopted AF in $\mathrm{ZM}$ have done so without the payments, but only on a limited area.

Financial support during the first years following adoption may therefore be instrumental to upscaling AF especially for the poorer households, as was also pointed out by Pagiola et al. (2007). PES schemes could provide such support if designed properly. In Costa Rica, for example, the largest part of the total PES is provided in the first and second year of adoption (Zbinden and Lee 2005). Monitoring is also required to ensure that land use changes generate the desired services as argued by Pagiola et al. (2007). Next to the provisioning services, that farmers in $\mathrm{ZM}$ have provided, efforts must therefore also be made to monitor and document the effects of AF on other types of ecosystem services such as biodiversity conservation, carbon sequestration in soils and tree biomass, and soil and water protection.

\section{Conclusions}

This paper described the strategies and economics of coffee farming systems based on studies among three groups of farmers, who are at different stages of the agro-ecological transition process. These groups of farmers reflected the diversity in terms of family size, farm area, land tenure and cropping systems, characteristic for family agriculture in the Zona da Mata. Based on our findings we conclude that:

1. There was a considerable diversity among the different farmers in their farming strategies and management of agroforestry and full-sun coffee production systems. This strongly affected the productivity and profitability of the systems and is thus an important source of information for further optimization of family agriculture.

2. Early adopters of AF had diversified towards production of different marketable products. The use of native trees in $\mathrm{AF}$ for this purpose, and for restoration of soil fertility (e.g., leguminous trees), had increased since the start of the experiments, while exotic tree species were eliminated.

3. The total production value for agroforestry systems was on average $43 \%$ higher than for full-sun coffee systems over a period of 12 years, despite somewhat higher establishment costs. The diversification of production renders additional income and offers a strategy for risk mitigation.

4. The agroforestry systems provide various ecosystem services in addition to agricultural goods. Future research should focus on the quantification and valuation of ecosystem services, as PES programs could help farmers to overcome establishment and learning costs when adopting AF.

Acknowledgments We are grateful to the farmers for providing inspiring moments and sharing unconditionally their enthusiasm with agroecology; to the CTA-ZM (Centre of Alternative Technologies of Zona da Mata) for providing valuable data and information; to CAPES (Coordenação de Aperfeiçoamento de Pessoal de Nível Superior) for providing a scholarship to the first author; to Daniel Orellana for the map. We thank Lijbert Brussaard for useful comments on an earlier version of the manuscript. This work was part of the agroBIODIVERSITY network of DIVERSITAS, the International Organization for Biodiversity Science.

Open Access This article is distributed under the terms of the Creative Commons Attribution Noncommercial License which permits any noncommercial use, distribution, and reproduction in any medium, provided the original author(s) and source are credited. 


\section{References}

Alavalapati JRR, Shrestha RK, Stainback GA, Matta JR (2004) Agroforestry development: an environmental economic perspective. Agrofor Syst 61-62(1):299-310

Bennett EM, Balvanera P (2007) The future of production systems in a globalized world. Front Ecol Environ 5(4): 191-198

Bliska FMdM, Vegro CLR, Júnior PCA, Mourão EAB, Cardoso CHS (2009) Custos de Produção de Café nas Principais Regiões Produtoras do Brasil. Informações Econômicas 39(9): $1-20$

Brown S, Gillespie AJR, Lugo AE (1989) Biomass estimation methods for tropical forests with applications to forest inventory data. For Sci 35:881-902

Brussaard L, Caron P, Campbell B, Lipper L, Mainka S, Rabbinge R, Babin D, Pulleman M (2010) Reconciling biodiversity conservation and food security: scientific challenges for a new agriculture. Curr Opin Environ Sustain 2(1-2):34-42

Buck LE, Milder JC, Gavin TA, Mukherjee I (2006) Understanding ecoagriculture: a framework for measuring landscape performance. Department of Natural Resources, Cornell University, Ithaca, p 54

Cardoso IM, Guijt I, Franco FS, Carvalho AF, Ferreira Neto PS (2001) Continual learning for agroforestry system design: University, NGO and farmer partnership in Minas Gerais, Brazil. Agric Syst 69(3):235-257

Cardoso I, Boddington C, Janssen B, Oenema O, Kuyper T (2003) Distribution of mycorrhizal fungal spores in soils under agroforestry and monocultural coffee systems in Brazil. Agrofor Syst 58(1):33-43

Carpenter SR, Mooney HA, Agard J, Capistrano D, DeFries RS, Daz S, Dietz T, Duraiappah AK, Oteng-Yeboah A, Pereira HM, Perrings C, Reid WV, Sarukhan J, Scholes RJ, Whyte A (2009) Science for managing ecosystem services: beyond the millennium ecosystem assessment. Proc Natl Acad Sci 106(5):1305-1312. doi:10.1073/pnas.0808772106

Casali VWD, Cardoso IM, MdCC Teixeira, Ferreira-Neto PS, Barbosa WA, Jucksch I, Mendonça ES, Ferrari EA, Fernandes EI, Gjorup GB, Franco FS, Carvalho AF, Mello CC (1997) Parque Estadual da Serra do Brigadeiro: Percepção, Uso e Estratificação do Ambiente. Universidade Federal de Viçosa, Viçosa

Chaves HML, Braga B, Domingues AF, Santos DGd (2004) Quantificação dos Benefícios Ambientais e Compensações Financeiras do "Programa do Produtor de Água" (ANA): I. Teoria. Revista Brasileira de Recursos Hídricos 9(3): $5-14$

Conway GR (1987) The properties of agroecosystems. Agric Syst 24(2):95-117

Costanza R (2000) Social goals and the valuation of ecosystem services. Ecosystems 3(1):4-10

CTA-ZM (2006) Monitoramento da sustentabilidade de Agroecossistemas-Construindo Indicadores. CTA/ZMCentro de Tecnologias Alternativas da Zona da Mata, Viçosa

Dean W (1995) With broadax and firebrand: the destruction of the Brazilian Atlantic forest. University of California Press, Berkeley
Duarte EMG (2007) Ciclagem de nutrientes por árvores em sistemas agroflorestais na Mata Atlântica. Dissertação (Mestrado em Solos e Nutrição de Plantas), Federal University of Viçosa, Viçosa

Duarte F, Mansinho MI, Barreira MM, Jones N, Lúcio C, Nunes A (eds) (2004) Overview of olive production cost analysis for Trás-os-Montes SMOPS, Working Paper No. 3. Overview of production cost for Sloping and Mountaniouos Olive Plantation Systems (SMOPS) under different circumstances, The future of olive plantation systems on sloping and mountainous land, scenarios for production and natural resource conservation, Lisboa

Egoh B, Reyers B, Rouget M, Richardson DM, Le Maitre DC, van Jaarsveld AS (2008) Mapping ecosystem services for planning and management. Agric Ecosyst Environ 127(1-2): $135-140$

Fernandes JM (2007) Taxonomia e etnobotânica de Leguminosae Adans. em fragmentos florestais e sistemas agroflorestais na Zona da Mata Mineira. Federal University of Viçosa, Viçosa

Ferrari E (1996) Desenvolvimento da Agricultura Familiar: a experiência do CTA-ZM. In: Alvarez VH, Fontes LEF, Fontes MPF (eds) O Solo nos Grandes Domínios Morfoclimáticos do Brasil e o Desenvolvimento Sustentado. JARD, Viçosa, pp 233-250

Filius A (1982) Economic aspects of agroforestry. Agrofor Syst 1(1):29-39

Franco FS (2000) Sistemas Agroflorestais: uma contribuição para a conservação dos Recursos Naturais na Zona da Mata de Minas Gerais. Doctor Scientiae, Federal University of Viçosa, Viçosa

Franco FS, Couto L, Carvalho AFd, Jucksch I, Fernandes Filho EI, Silva E, Meira Neto JAA (2002) Quantificação de erosão em sistemas agroflorestais e convencionais na Zona da Mata de Minas Gerais. Revista Árvore 26:751-760

Geilfus F (2000) 80 Herramientas para el Desarrollo Participativo: Diagnóstico, Planificación, Monitoreo, Evaluación www.territoriosdacidadania.gov.br/o/890312. edn. GTZDeutsche Gesellschaft für Technische Zusammenarbeit/ IICA-Instituto Interamericano de Cooperación para la Agricultura, San Salvador

Golfari L (1975) Zoneamento Ecológico do Estado de Minas Gerais para reflorestamento-Série Técnica, 3. CPFRC, Belo Horizonte

Harvey CA, Komar O, Chazdon R, Ferguson BG, Finegan B, Griffith DM, MartÍNez-Ramos M, Morales H, Nigh R, Soto-Pinto L, Wishnie MVANBM (2008) Integrating agricultural landscapes with biodiversity conservation in the mesoamerican hotspot. Conserv Biol 22(1):8-15

IBGE (2000) Censo Demográfico (Minas Gerais). Fundação Instituto Brasileiro de Geografia e Estatística, Rio de Janeiro/RJ

Jaramillo-Botero C (2007) Resposta de cafeeiros ao sombreamento e à dinâmica de serapilheira em condições de sistema agroflorestal. Universidade Federal de Viçosa, Viçosa

Jose S (2009) Agroforestry for ecosystem services and environmental benefits: an overview. Agrofor Syst 76(1):1-10

Klingen K (2009) Visions on soils and soil management of agroecological and conventional farmers in Minas Gerais. Wageningen University, Wageningen 
Lundberg J, Moberg F (2008) Ecological in Ethiopia-farming with nature increases profitability and reduces vulnerability. Swedish Society for Nature Conservation (SSNC), Stockholm

MEA (2005) Millennium ecosystem assessment-ecosystems and human well-being: biodiversity synthesis. World Resources Institute, Washington DC

Miranda D (2002) "Those folks with a lot of dirt in their coffee fields"-agroecological innovations and peasants livelihood sustainability: the synergy of peasants, grassroot movements and an NGO in Araponga, Brazil. Wageningen University and Research Center, Wageningen

Molua EL (2005) The economics of tropical agroforestry systems: the case of agroforestry farms in Cameroon. For Policy Econ 7(2):199-211

Montagnini F, Nair PKR (2004) Carbon sequestration: an underexploited environmental benefit of agroforestry systems. Agrofor Syst 61-62(1):281-295

Myers N, Mittermeier RA, Mittermeier CG, da Fonseca GAB, Kent J (2000) Biodiversity hotspots for conservation priorities. Nature 403(6772):853-858

Ouinsavi C, Sokpon N (2008) Traditional agroforestry systems as tools for conservation of genetic resources of Milicia excelsa Welw. C.C. Berg in Benin. Agrofor Syst 74(1): $17-26$

Pagiola S, Agostini P, Gobbi J, de Haan C, Ibrahim M, Murgeitio E, Ramírez E, Rosales M, Pablo Ruóz J (2004) Paying for biodiversity conservation services in agricultural landscapes. The World Bank Enviroment Department, Washington, pp 1-37

Pagiola S, Ramírez E, Gobbi J, de Haan C, Ibrahim M, Murgueitio E, Ruíz JP (2007) Paying for the environmental services of silvopastoral practices in Nicaragua. Ecol Econ 64(2):374-385

Pascual U, Perrings C (2007) Developing incentives and economic mechanisms for in situ biodiversity conservation in agricultural landscapes. Agric Ecosyst Environ 121(3): 256-268

Perfecto I, Vandermeer J (2008) Biodiversity conservation in tropical agroecosystems: a new conservation paradigm. Ann N Y Acad Sci 1134:173-200

Perfecto I, Vandermeer J, Mas A, Soto-Pinto L (2005) Biodiversity, yield, and shade coffee certification. Ecol Econ 54:435-446

Ribeiro MC, Metzger JP, Martensen AC, Ponzoni FJ, Hirota MM (2009) The Brazilian Atlantic forest: how much is left, and how is the remaining forest distributed? Implications for conservation. Biol Conserv 142(6):1141-1153

Ricci MSF, Oliveira NG (2007) Custos de Implantação e Manutenção e Receitas Brutas Obtidas com o Cultivo Orgânico de Café nos sistemas a Pleno Sol e Consorciado à Bananeira e Eritrina. Boletim de Pesquisa e Desenvolvimento 18:16

Rice RA (2008) Agricultural intensification within agroforestry: the case of coffee and wood products. Agric Ecosyst Environ 128(4):212-218

Sala O, Montes C (2007) La Evaluación de los Ecosistemas del Milenio: las relaciones entre el funcionamiento de los ecosistemas y el bienestar humano. Ecosistemas 16(3)

Schroth G, Laderach P, Dempewolf J, Philpott S, Haggar J, Eakin H, Castillejos T, Garcia Moreno J, Soto Pinto L, Hernandez R, Eitzinger A, Ramirez-Villegas J (2009) Towards a climate change adaptation strategy for coffee communities and ecosystems in the Sierra Madre de Chiapas, Mexico. Mitig Adapt Strateg Glob Change 14(7):605-625

Siqueira LC (2008) Levantamento Florístico e Etnobotânico do Estrato Arbóreo em Sistemas Naturais e Agroflorestais, Araponga, Minas Gerais. Mestrado, Federal University of Viçosa, Viçosa

Souza HN (2006) Systemizing participatory experiences with agroforestry systems: towards to a sustainability of family agriculture in the Zona da Mata of Minas Gerais. MS, Federal University of Brazil, Viçosa

Souza HN, Cardoso IM, Fernandes J, Garcia F, Bonfim V, Santos A, Carvalho A, Mendonça E (2010) Selection of native trees for intercropping with coffee in the Atlantic Rainforest biome. Agrofor Syst 1:1-16. doi:10.1007/s10457010-9340-9

SSNC (2008) Ecological in Ethiopia-farming with nature increases profitability and reduces vulnerability. Swedish Society for Nature Conservation (SSNC), Stockholm

Teixeira AMG, Soares-Filho BS, Freitas SR, Metzger JP (2009) Modeling landscape dynamics in an Atlantic Rainforest region: implications for conservation. For Ecol Manag 257(4):1219-1230

Vaast P, Bertrand B, Perriot JJ, Guyot B, Génard M (2006) Fruit thinning and shade improve bean characteristics and beverage quality of coffee Coffea arabica L. under optimal conditions. J Sci Food Agric 86:197-204

Zbinden S, Lee DR (2005) Paying for environmental services: an analysis of participation in Costa Rica's PSA Program. World Dev 33(2):255-272 